\title{
Cloning, expression and characterization of Trypanosoma evansi Paraflagellar Rod 2 gene
}

\author{
S. Sivajothi ${ }^{1 *}$, V. C. Rayulu ${ }^{1}$, P. M. Kondaiah ${ }^{1}$, D. Sreenivasulu ${ }^{2}$, CH. Srilatha ${ }^{3}$, \\ D. V. R. Sai Gopal ${ }^{4}$, B. Bhaskar Reddy ${ }^{5}$, and B. Sudhakara Reddy ${ }^{6}$ \\ ${ }^{1}$ Department of Veterinary Parasitology, Sri Venkateswara Veterinary University, Tirupati, India \\ ${ }^{2}$ Department of Veterinary Microbiology, Sri Venkateswara Veterinary University, Tirupati, India \\ ${ }^{3}$ Department of Veterinary Pathology, Sri Venkateswara Veterinary University, Tirupati, India \\ ${ }^{4}$ Department of Virology, Sri Venkateswara University, Tirupati, India \\ ${ }^{5} R A R S, A N G R A U$, Tirupati, India \\ ${ }^{6}$ Department of Veterinary Medicine, Sri Venkateswara Veterinary University, Tirupati, India
}

\begin{abstract}
SIVAJOTHI, S., V. C. RAYULU, P. M. KONDAIAH, D. SREENIVASULU, CH. SRILATHA, D. V. R. SAI GOPAL, B. BHASKAR REDDY, B. SUDHAKARA REDDY: Cloning, expression and characterization of Trypanosoma evansi Paraflagellar Rod 2 gene. Vet. arhiv 89, 97-106, 2019.
\end{abstract}

\section{ABSTRACT}

Paraflagellar rod is the major structural component of the trypanosomatid flagellum and is identified as a complex lattice of filaments which runs parallel to the axoneme throughout most of the flagellar length. The present study was carried out to investigate the existence of the paraflagellar rod (PFR 2) gene in Trypanosoma evansi infecting Indian cattle. Local isolates of $T$. evansi collected from naturally infected cow were multiplied in Wistar rats. Complementary DNA (cDNA) was synthesized from the RNA of host cell free $T$. evansi parasites by reverse transcription. The gel purified PCR product (PFR 2 gene of $T$. evansi) was cloned into the pTZ57R/T vector system. The nucleotide sequence of the PFR 2 gene of the T. evansi S.V.V.U. isolate (Accession No. KT277497) obtained in the present study revealed $100 \%$ homology with T. evansi China isolate and $99 \%$ homology with $T$. evansi Izatnagar and Bikaner isolates. The recombinant protein was sub-cloned into $\mathrm{pET}$ 32a and expressed in the BL21 (DE3) pLysS expression system. The PFR 2 gene of T. evansi S.V.V.U. isolate was further characterized by determination of its protein profile with SDS-PAGE and western blotting. Indirect ELISA was optimized for detection of the specific antibody titre against the recombinant protein of the PFR 2 gene of $T$. evansi. In the kinetoplastid species the PFR 2 gene is highly conserved. Therefore the PFR 2 gene was suggested as a vaccine candidate, as well as a diagnostic antigen.

Key words: Andhra Pradesh, India; Trypanosoma evansi; cattle; paraflagellar rod (PFR) 2 gene; cloning and expression

\footnotetext{
*Corresponding author:
}

S. Sivajothi, Department of Veterinary Parasitology, Sri Venkateswara Veterinary University - Tirupati, India, E-mail: sivajothi579@gmail.com 
S. Sivajothi et al.: Cloning, expression and characterization of Trypanosoma evansi Paraflagellar Rod 2 gene

\section{Introduction}

Trypanosoma evansi, the causative agent of surra is prevalent in different parts of the world infecting numerous domestic and wild animal species. Trypanosoma evansi infections are reported regularly in domestic and wild animals in India, particularly where the environment is suitable for the breeding of insect vectors (SIVAJOTHI and REDDY, 2018). The economic losses due to surra mainly depend on the immune status of the individual animal, the strain variation of the parasites and the presence of other concurrent diseases. It causes huge losses in production and the mortality of animals in fatal cases (PATHAK and CHHABRA, 2010; REDDY et al., 2016). The successful control of surra requires the development of a safe and efficacious vaccine. Development of strategies for invariant antigen identification and their application as futuristic vaccine targets have been in the centre stage of trypanosome research (MAHARANA et al., 2014). The Trypanosoma evansi PFR 2 gene, which encodes the major structural component of the paraflagellar rod, is highly pathogenic and restricted to the flagella of kinetoplastids. Nucleotide sequencing of the PFR 2 gene of T. evansi may be useful to identify the function of this gene and encode a protein (SANJAY KUMAR et al., 2013). Lately, research on the paraflagellar rod proteins present in the kinetoplastid flagellum is gaining greater interest in this perspective. The present study was designed to investigate the existence of the paraflagellar rod gene in T. evansi infecting Indian cattle.

\section{Materials and methods}

Propagation and purification of T. evansi. Isolates of T. evansi were collected from clinically ill cattle and maintained in Wistar rats for bulk harvest of parasites. Purification of the T. evansi parasites was done by Diethyl amino-ethyl cellulose anion exchange (DEAE) column chromatography (LANHAM and GODFREY, 1970). The isolates of T. evansi recovered from the cattle were named S.V.V.U. isolates, i.e. according to the geographical location of research.

RT-PCR amplification of the PFR gene of T. evansi. Total RNA was extracted directly from the host cell-free trypanosomes according to CHONCZYNSKI and SACCHI (1987) using a Trizol reagent (Invitrogen, CA, U.S.A). The purity and concentration of the eluted RNA was determined with Nanodrop ${ }^{\circledR}$. From the total RNA, cDNA was synthesized by RT-PCR using an oligo-dT primer and Revert Aid TM H minus first strand cDNA synthesis kit (Thermo Scientific, USA). Primers were designed on the basis of an open reading frame of the publicly available sequence of T. evansi (GenBank Accession No. EU258755) using Primer - Blast Programme (SIVAJOTHI et al., 2018).

Forward primer (SSJ-F: 5'- GGAATTCATGAGCGGGAAAGGAAGTTGAAG 3')

Reverse primer (SSJ-R: 5'- CCCAAGCTTCTGAGTGATCTGCGGCATCGTG -3') 
The RT-PCR products of $1800 \mathrm{bp}$ size were excised from the gel and purified using a QIA quick gel extraction kit (QIAGEN, Germany).

Construction of the recombinant plasmid and transformation into E. coli. The gel purified PCR product (PFR 2 gene of T. evansi) was cloned into a pTZ57R/T vector system. The recombinant plasmid was transformed into competent Escherichia coli DH5 $\alpha$ using the heat shock transformation method. Finally, the recombinant plasmid was extracted from the transformed DH5 $\alpha$ cells following the standard protocol (SAMBROOK and RUSSELL, 2001). The presence of the inserts was confirmed initially by Colony-PCR and then by Plasmid-PCR. The positive clone was custom sequenced.

Expression of the PFR 2 gene of T. evansi. The isolated recombinant plasmid was double digested with EcoR I and Hind III restriction enzyme, further sub-cloned into pET 32a, and expressed in the BL21 (DE3) pLysS expression system. Screening of the recombinant plasmids of the PFR 2 gene of T. evansi was carried out by plasmid PCR and restriction enzyme digestion.

Induction of expression. Five positive colonies of E. coli strain BL 21 harbouring the desired clone (recombinant plasmid) were diluted with Isopropyle- $\beta$-thiogalactopyranoside (IPTG) to a final concentration of 0.2-1.0 mM. The expression of the recombinant protein of T. evansi PFR 2 gene was analysed by SDS-PAGE (LAEMMLI, 1970).

Purification of the recombinant protein. The recombinant protein of the PFR 2 gene of $T$. evansi was purified by nickel affinity chromatography His-binding resins with six histidine residues at the amino terminal bound (LUHRS et al., 2003). The PFR 2 gene of the T. evansi S.V.V.U. isolate was further characterized by western blotting against hyper immune serum. The western blotting technique was used for specific identification of proteins from the the mixture of proteins in the obtained sample. In this method, a labelled antibody against a particular protein is used to identify the desired protein, so it is a specific test. Indirect ELISA was optimized for detection of the specific antibody titre against the recombinant protein of the PFR 2 gene of T. evansi (TAMURA et al., 2007).

\section{Results and discussion}

A single band at $1800 \mathrm{bp}$ of the T. evansi PFR 2 gene was observed in the present study when compared against the $1 \mathrm{~kb}$ ladder. The concentration of the purified PCR amplicon was measured as $40 \mathrm{ng} / \mu \mathrm{L}$. These purified PCR products of the PFR 2 gene of $T$. evansi were further used for cloning into a $\mathrm{pTZ} 57 \mathrm{R} / \mathrm{T}$ vector system. The selection of positive colonies was done by the blue-white colony (Fig. 1) screening method. The presence of inserts was confirmed initially by Colony PCR (Fig. 2) and then by plasmid PCR. Custom sequencing was undertaken for the positive clone.

The coding region of a gene, also known as the CDS (from the coding sequence), is that portion of a gene's DNA or RNA that codes for protein. 


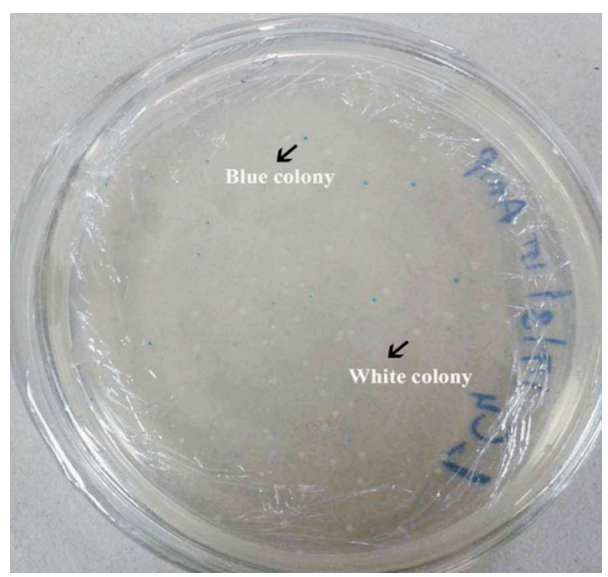

Fig. 1. Transformation of E.coli DH5 $\alpha$ cells with the ligated PFR 2 gene of T. evansi. White colony - recombinant (transformed) colony, blue colony - non recombinant colony.

The nucleotide sequence of the PFR 2 gene of the T. evansi (KT277497) obtained in the present study had 100\% homology with T. evansi (GenBank Accession No. EU258755), T. brucei brucei partial mRNA (GenBank Accession No. XM 842234), T. brucei (GenBank Accession No. X14819), T. brucei gambiense partial mRNA (GenBank Accession No. XM 842234) and T. brucei brucei complete cds (GenBank Accession No. L30155). The nucleotide sequence also showed $99 \%$ homology with T. evansi complete cds (GenBank Accession No. GQ392136), T. evansi partial cds (GenBank Accession No. FJ901341), T. cruzi complete cds (GenBank Accession No. FJ22246)1, T. evansi Bikaner isolate partial cds (GenBank Accession No. JX020770), T. cruzi complete cds (GenBank Accession No. M97548), T. cruzi partial mRNA (GenBank Accession No.XM809076), Leishmania infantum PFR 2, mRNA complete cds (Genbank Accession No. XM001464594) and Crithidia fasciculata PFR 2, mRNA complete cds (Genbank Accession No. AY 568293). Variations in nucleotide mutations were observed at positions $861(\mathrm{~T} \rightarrow \mathrm{G}), 928(\mathrm{~T} \rightarrow \mathrm{G})$ and $1299(\mathrm{~T} \rightarrow \mathrm{C})$ with the T. evansi Izatnagar isolate, and at positions $714(\mathrm{G} \rightarrow \mathrm{A}), 861$ $(\mathrm{T} \rightarrow \mathrm{G}), 901(\mathrm{C} \rightarrow \mathrm{T})$ and $987(\mathrm{~T} \rightarrow \mathrm{C})$ with the T. evansi Bikaner isolate, when compared to the nucleotide sequence of the PFR 2 gene of the T. evansi S.V.V.U. isolate.

The total length of the amino acid of the PFR 2 gene of the T. evansi S.V.V.U. isolate was 600 amino acids. The amino acid mutation in the PFR 2 gene of the T. evansi S.V.V.U. isolate displayed regularity at four positions, that is, $287(\mathrm{~N} \rightarrow \mathrm{K}), 310(\mathrm{~L} \rightarrow \mathrm{V}), 433(\mathrm{~F} \rightarrow \mathrm{S})$ and $562(\mathrm{~V} \rightarrow \mathrm{A})$. 
S. Sivajothi et al.: Cloning, expression and characterization of Trypanosoma evansi Paraflagellar Rod 2 gene

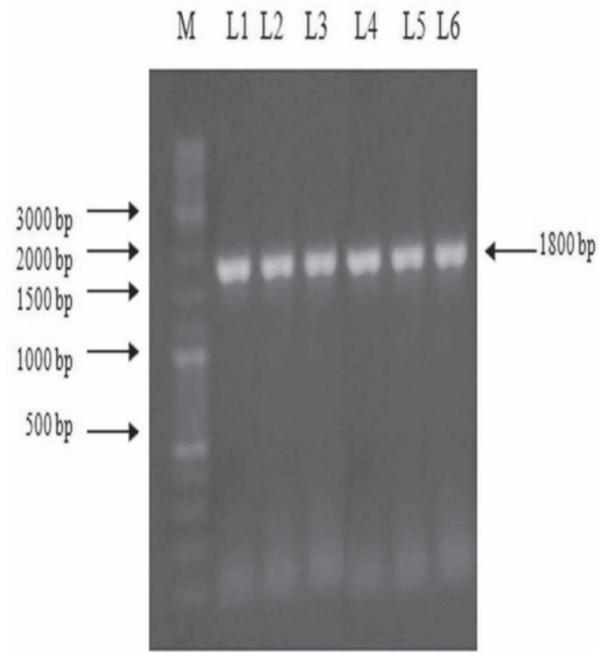

Fig. 2. Conformation of recombinant clone of the PFR 2 gene of T. evansi by colony-PCR. M - 1 kb DNA Ladder; L1 to L6 - Colony - PCR product of the PFR 2 gene of T. evansi

However, the T. evansi PFR 2 gene sequence reported by ABDILLE et al. (2008) from China showed 100\% similarity with sequences of T. brucei (GenBank Accession No. XM842234) and T. brucei (GenBank Accession No. X14819). The nucleotide sequence of thePFR 2 gene of Izatnagar isolate (MAHARANA et al., 2011) showed 99.9\% homology with the China isolates and $99.9 \%, 82.4 \%, 75.3 \%$ and $74.8 \%$ sequence homology with the published sequences of T. brucei, T. cruzi, L. infantum and C. fasciculata, respectively.

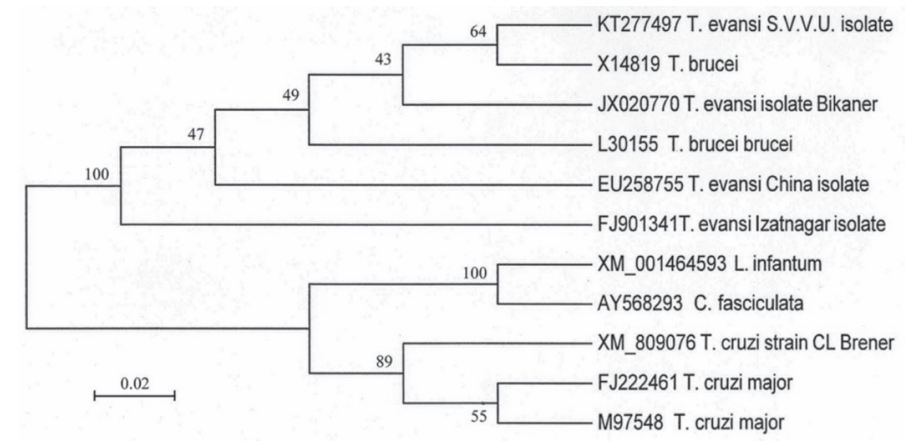

Fig. 3. Bootstrap NJ tree constructed on the basis of the PFR 2 gene sequence of T. evansi in comparison with sequences already reported from other geographical regions showing bootstrap values at the nodes 
Tree topology based on the Neighbor-joining (NJ) method showed close homology with other Trypanosomatidae species sequences with $100 \%$ bootstrap values (Fig. 3). The percentage of the replicate tree in which the associated taxa clustered together in the bootstrap test (1000 replicates) was shown next to the branches.

The procedure adopted in the present investigation for phylogenetic analysis of the PFR 2 gene of the T. evansi S.V.V.U. isolate was according to ABDILLE et al. (2008) and SANJAY KUMAR et al. (2013), who also constructed a phylogenetic tree based on the Neighbor-Joining method which showed close homology with other Trypanosomatidae species sequences with $100 \%$ bootstrap values. The NJ, bootstrap consensus tree inferred from 1000 replicates is taken to represent the evolutionary history of the taxa analysed. However, MAHARANA et al. (2011), used the sequence pair wise distance of the nucleotides of the PFR 2 gene instead of a phylogenetic tree.

The protein profile of the induced and uninduced lysates along with the control vector transformed $E$. coli lysates, were determined by SDS-PAGE. The appearance of a clear band with an approximate molecular weight of $90 \mathrm{KDa}$ (Fig. 4) in the induced E. coli lysates and no band in the uninduced or control E. coli lysates was observed.

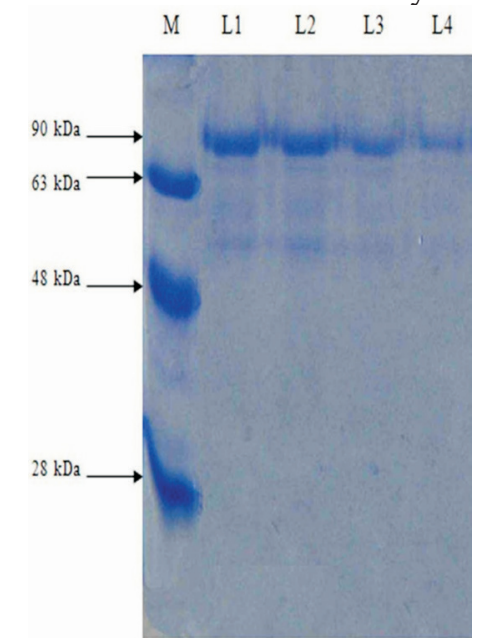

Fig. 4. Molecular weight determination of the purified recombinant protein of the PFR 2 gene of T. evansi by SDS-PAGE. M - Pre stained protein molecular weight marker; L1, L2, L3 and L4 Elutes from Ni-NTA agarose column.

The PFR 2 gene of the T. evansi S.V.V.U. isolate was further characterized by western blotting against hyper immune serum (Fig. 5). The antibody titre of the hyper immune sera, raised in two rabbits, against the PFR 2 gene of T. evansi was estimated as 6.76 and 
5.63 ELISA units, respectively. It is evident that the PFR 2 gene product elicited a very good immune response. However, further study is required to know the protective effect of the PFR 2 antibodies in laboratory animals.

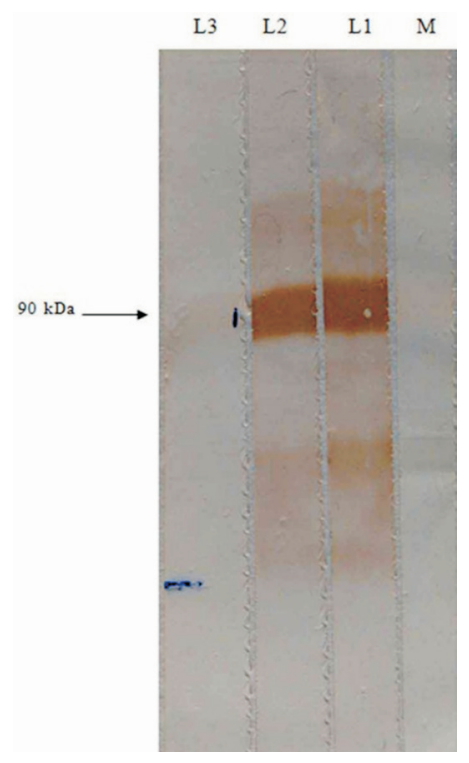

Fig. 5. Western blot analysis of the purified recombinant protein of the PFR 2 gene of T. evansi. M - Pre stained protein molecular weight marker; L1 and L2 - Purified recombinant protein of the PFR 2 gene of T. evansi; L3 - Negative control.

The present research findings on the PFR 2 gene sequence homology with the nucleotide sequence of other trypanosomatids hypothesizes that vaccination with PFR proteins could be effective not only in different strains within a trypanosome species, but also against other species of the same genus. A similar conclusion on the vaccine potentiality of PFR 2 was drawn by SANJAY KUMAR et al. (2013). MAHARANA et al. (2011) also reported the conserved nature of various PFR 2 genes present in kinetoplastids, and recommended the use of proteins for development of a vaccine.

PFR could also be used for development of diagnostics, and also for therapeutic intervention of pathogenic trypanosomatids, without any deleterious effect on their mammalian hosts. The possibility exists of cross-reaction with other pathogenic and nonpathogenic trypanosomes in India. Cloning, expression and characterization of the PFR 2 gene of $T$. evansi of the cattle isolate carried out in the present investigation is probably the first report in India. The findings of the present study confirmed the existence of the PFR 2 gene in Indian cattle isolates of T. evansi. Further study is required to explore the 
S. Sivajothi et al.: Cloning, expression and characterization of Trypanosoma evansi Paraflagellar Rod 2 gene

PFR 2 gene of T. evansi as a potential candidate for diagnostic and vaccine targeting against surra in animals.

\section{Acknowledgements}

The authors expressed sincere thanks to the authorities of Sri Venkateswara Veterinary University, Sri Venkateswara University and RARS, Tirupati for providing the necessary facilities to carry out this work.

\section{Author's Contribution}

This is part of the $\mathrm{PhD}$ research work of the first author; the second, third, fourth and fifth authors are the advisory committee for the $\mathrm{PhD}$ programme, and the sixth and seventh authors helped in technical support and instrumentation, and the eighth author provided financial support for completion of the $\mathrm{PhD}$ research work.

\section{Conflicts of interest}

The authors declare that they have no conflicts of interest.

\section{Ethical approval}

All applicable international, national, and/or institutional guidelines for the care and use of animals were followed.

\section{Reference}

ABDILLE, M. H., Y.S. LI, X. SUO, G. MKOJI (2008): Evidence for the existence of paraflagellar rod protein 2 gene in Trypanosoma evansi and its conservation among other kinetoplastid parasites. Exp. Parasitol. 118, 614-618.

DOI: 10.1016/j.exppara.2007.11.011

CHONCZYNSKI, P., N. SACCHI (1987): Single-step method of RNA isolation by acid guanidinium thiocyanate-phenol-chloroform extraction. Ann. Biochem. 162, 156-159.

LAEMMLI, U. K (1970): Cleavage of structural protein during the assembly of head of bacteriophage T4. Nature 227, 680-685.

DOI: $10.1038 / 227680 \mathrm{a} 0$

LANHAM, S. M., G. D. GODFREY (1970): Isolation of salivarian trypanosomes from man and other animals using DEAE-cellulose. Exp. Parasitol. 28, 521- 534.

DOI: 10.1016/0014-4894(70)90120-7

LUHRS, K. A., D. L. FOUTS, J. E. MANNING (2003): Immunization with recombinant paraflagellar rod protein induces protective immunity against Trypanosoma cruzi infection. Vaccine 21, 3058-3069.

DOI: $10.1016 / \mathrm{S} 0264-410 \mathrm{X}(03) 00108-7$

MAHARANA, B. R., J. R. RAO, A. K. TEWARI, H. SINGH (2011): Cloning and expression of paraflagellar rod protein (PFR 2) gene of Trypanosoma evansi. J. Vet. Parasitol. 25, 118-123. 
S. Sivajothi et al.: Cloning, expression and characterization of Trypanosoma evansi Paraflagellar Rod 2 gene

MAHARANA, B. R., J. R.RAO, A. K. TEWARI, H. SINGH, O. K. RAINA, I. M. ALLAIE, A, VARGHESE (2014): Molecular characterization of paraflagellar rod protein gene in Trypanosoma evansi. J. Appl. Anim. Res. 42, 1-5.

DOI: $10.1080 / 09712119.2013 .795894$

PATHAK, K. M. L., M. B. CHHABRA (2010): Parasites and parasitic diseases of the camel in India: a review. Indian J. Anim. Sci. 80, 699-706.

REDDY, B. S., K. N. KUMARI, S. SIVAJOTHI, V. C.RAYULU (2016): Haemato-biochemical and thyroxin status in Trypanosoma evansi infected dogs. J. Parasit. Dis. 40, 491-495.

DOI: $10.1007 / \mathrm{s} 12639-014-0531-6$

SAMBROOK, J., D. W. RUSSELL (2001): Molecular cloning: A Laboratory Manual. $3^{\text {rd }}$ ed. Cold Spring Harbor Laboratory Press, Cold spring Harbor, NY.

SANJAY KUMAR, G. S., S. K. MANOHAR, K. GHORUI, S. KASHYAP, N. MAHERCHANDANI, PATIL (2013): Amplification, cloning and sequence analysis of paraflagellar rod 2 gene of Trypanosoma evansi isolated from Indian dromedaries. Vet. Practitioner 14, 204-207.

SIVAJOTHI, S., B. S. REDDY (2018): Trypanosoma evansi infection in a cat-a rare case. Comp. Clin. Pathol. 27, 115-116.

DOI: $10.1007 / \mathrm{s} 00580-017-2560-\mathrm{x}$

SIVAJOTHI, S., V. C. RAYULU, K. M. KONDAIAH, D. SREENIVASULU, C. SRILATHA, B. S. REDDY (2018): Standardization of Reverse Transcriptase-Polymerase Chain Reaction for the Detection of Paraflagellar Rod Gene of Trypanosoma evansi in Cattle. International Journal of Livestock Research. 8, 94-100.

DOI: $10.5455 /$ ijlr.20171021090945

TAMURA, K., J. DUDLEY, M. NEI, S. KUMAR (2007): MEGA4: Molecular Evolutionary Genetics Analysis (MEGA) software version 4.0. Mol. Biol. Evol. 24, 1596-1599.

DOI: $10.1093 / \mathrm{molbev} / \mathrm{msm} 092$

Received: 3 October 2017

Accepted: 8 November 2018

SIVAJOTHI, S., V. C. RAYULU, P. M. KONDAIAH, D. SREENIVASULU, CH. SRILATHA, D. V. R. SAI GOPAL, B. BHASKAR REDDY, B. SUDHAKARA REDDY: Kloniranje, ekspresija i karakterizacija paraflagelarnog gena Rod 2 bičaša Trypanosoma evansi. Vet. arhiv 89, 97-106, 2019.

\section{SAŽETAK}

Paraflagelarni štapić glavna je strukturna komponenta tripanosomskog biča i dio je kompleksa filamenaza koji teku paralelno s aksonemom duž biča. Istraživanje je provedeno kako bi se ispitalo postojanje paraflagelarnog gena Rod 2 (PFR2) u bičaša Trypanosoma evansi koji invadira goveda u Indiji. Lokalni izolat $T$. evansi prikupljen od prirodno invadiranih krava umnožen je u Wistar štakora. Komplementarna DNA (cDNA)

Vet. arhiv 89 (1), 97-106, 2019 
S. Sivajothi et al.: Cloning, expression and characterization of Trypanosoma evansi Paraflagellar Rod 2 gene

sintetizirana je iz RNA obrnutom transkripcijom iz stanica neinvadiranih nositelja T. evansi parazita. Pročišćeni PCR produkt (gen PFR2 bičaša T. evansi) kloniran je u vektorski sustav pTZ57R/T. Nukleotidna sekvencija gena PFR2 bičaša T. evansi, izolat S.V.V.U. (pristupni broj KT277497) dobivena u ovom istraživanju pokazala je 100 \%-tnu sličnost s izolatom T. evansi China i 99 \%-tnu s izolatom T. evansi Izatnagar i Bikaner. Rekombinantni protein ponovno je kloniran u sustavu pET 32a i prikazan u sustavu BL21 (DE3) pLysS. Gen PFR2 bičaša T. evansi, izolat S.V.V.U. dalje je karakteriziran određivanjem proteinskog profila metodama SDS-PAGE i Western blotting. Indirektni test ELISA optimiziran je za dokaz titra specifičnih protutijela za rekombinantni protein gena PFR2 bičaša T. evansi. U kinetoplastida gen PFR2 izrazito je očuvan. Stoga bi se gen PFR2 mogao upotrijebiti za cjepivo te kao dijagnostički antigen.

Ključne riječi: Andhra Pradesh, India; Trypanosoma evansi; goveda; paraflagelarni gen PFR2; kloniranje i ekspresija 